\section{Resistance to Phytophthora Root Rot in Contemporary Rhododendron Cultivars}

\author{
Stephen L. Krebs ${ }^{1}$ \\ The Holden Arboretum, 9500 Sperry Road, Kirtland, OH 44094 \\ Michael D. Wilson \\ Department of Pediatrics, Case Western Reserve University, Cleveland, \\ $\mathrm{OH} 44106$
}

Additional index words. Ericaceae, Phytophthora cinnamomi, disease resistance

\begin{abstract}
Fifty-seven rhododendron cultivars (genus Rhododendron L.) were screened for resistance to root rot caused by Phytophthora cinnamomi, using two levels of inoculum. While a majority $(77 \%)$ of genotypes was susceptible, six cultivars had moderate resistance, and seven cultivars exhibited a high level of resistance to the disease. In these resistant groupings, the severity of root rot did not increase significantly with a 3-fold increase in inoculum. Comparisons of micropropagated and conventionally propagated plants revealed no significant difference in root rot ratings. The species $R$. keiskei was identified as a possible source of resistance to $P$. cinnamomi in two of the rhododendron cultivars.
\end{abstract}

Root rot caused by Phytophthora cinnamomi Rands can result in significant levels of rhododendron mortality in both nurseries and home gardens. Commercial growers engaged in container production are able to suppress disease development by using composted hardwood and pine bark in potting mixes (Benson, 1984; Hoitink et al., 1977). Fungicide drenches are also effective in reducing the incidence of root rot in containergrown rhododendrons (Benson, 1987).

In home gardens and in nurseries where rhododendrons are field grown, control of the disease is more difficult. In these situations, genetically conferred host resistance would provide a valuable line of defense against the pathogen. However, the array of resistant genotypes currently available to the industry and consumers is small. Screenings of rhododendrons performed over 25 years ago demonstrated that most genotypes are susceptible, with fewer than 20 out of 336 rhododendron cultivars identified as having moderate to high levels of root rot (Hoitink and Schmitthenner, 1974). That study found no evidence of immunity to the disease, and the plants designated "resistant" were those in which root rot damage was minimal (e.g., confined to youngest roots).

Despite their resistant attribute, these previously tested rhododendron cultivars are not widely distributed in the nursery trade. Nor, to

Received for publication 9 Apr. 2001. Accepted for publication 11 Oct. 2001. A contribution of the David G. Leach Research Station of the Holden Arboretum. We are indebted to Briggs Nursery and the late Bruce Briggs for supplying hundreds of micropropagated rhododendrons. Anne Dorrance generously provided fresh cultures of $P$. cinnamomi and reviewed an earlier draft of this paper. Don Whitney assisted with the greenhouse work.

${ }^{1}$ To whom reprint requests should be addressed. E-mail address: slkrebs@ncweb.com our knowledge, have they been used in breeding programs aimed at increasing the frequency and level of root rot resistance among cultivated rhododendrons. As a first step in initiating such a program, we have screened a group of popular, contemporary hybrids in order to identify additional sources of resistance to $P$. cinnamomi.

\section{Materials and Methods}

Fifty-five micropropagated rhododendron cultivars were supplied by Briggs' Nursery (Olympia, Wash.) as 1-year-old rooted plants. Although thousands of cultivars have been commercially adopted (and many abandoned) in the past 150 years of rhododendron breeding, the plants selected for this study are cold hardy, readily available hybrids that have been introduced recently from international breeding programs. All but seven have not previously been tested for resistance to $P$. cinnamomi.

The dormant plants were maintained in cold storage for a month, then transplanted into 4 -inch pots in a warm $\left(20 \pm 5^{\circ} \mathrm{C}\right)$ greenhouse. The potting mix consisted of sterilized 1 peat : 1 perlite (by volume) mixed with Sierra Blend $17 \mathrm{~N}-6 \mathrm{P}-12 \mathrm{~K}$ fertilizer (Scotts Co., Maryville, Ohio) containing micronutrients $\left(1.9 \mathrm{~L} \cdot \mathrm{m}^{-3}\right)$, Aquagro (Aquacontrols, Cherry Hill, N.J.) wetting agent $\left(3.1 \mathrm{~L} \cdot \mathrm{m}^{-3}\right)$, and dolomitic lime $\left(1.4 \mathrm{~L} \cdot \mathrm{m}^{-3}\right)$, with an initial $\mathrm{pH}$ of 5.0. After the first set of leaves had expanded, the pots were watered weekly with 100 ppm 20N-20P-20K fertilizer. The plants were grown for 3 months prior to inoculation, at which time they had initiated a second flush of growth.

Two cultivars not available from micropropagators were conventionally propagated to serve as controls, 'Caroline' (resistant) and 'Lee's Dark Purple' (susceptible) (Hoitink and Schmitthenner, 1974). Eight additional cultivars were propagated from cuttings to provide a disease comparison to their tissue culture-derived counterparts. Shoot cuttings were rooted the previous fall following a $1 \%$ IBA treatment, held dormant in cold storage, and then transplanted on the same schedule as the micropropagated plants.

Phytophthora cinnamomi isolate 544 used in an earlier report (Hointink and Schmitthenner, 1974) was supplied by Anne Dorrance (Dept. of Plant Pathology, Ohio State Univ.) and subsequently cultured in hemp seed extract (Schmitthenner and Bhat, 1994) for 2 weeks under continuous light. Inoculum was prepared by fragmenting the mycelial mat in sterilized distilled water using an Ultra-TurrakT25 homogenizer (IKALabortechnik, Concinatti) at $9500 \mathrm{rpm}$ for 15 $\mathrm{s}$. This treatment resulted in dispersed chlamydospores and hyphal fragments that contained cytoplasm when viewed under a light microscope. Dilutions of the stock inoculum were plated on lima bean agar (Schmitthenner and Bhat, 1994) to estimate colony-forming units (CFU) concentrations.

Cultivar replicates were treated with one of two inoculum levels. All 57 received the lower level of $10 \mathrm{CFU}$ per pot, and 55 were exposed to $30 \mathrm{CFU}$ per pot, with four replicate pots per treatment (cultivar $\times$ inoculum level). A pipetter was used to inject $1 \mathrm{~mL}$ of diluted inoculum stock (containing 10 or $30 \mathrm{CFU}$ ) 2 to $3 \mathrm{~cm}$ from the collar of each plant, just below the soil surface. Pots were watered to saturation for three consecutive days following inoculation, and two times weekly thereafter. Greenhouse temperatures were maintained at 24 to $32^{\circ} \mathrm{C}$ following treatment with $P$. cinnamomi.

Pots were arranged in a randomized complete-block design, with four blocks. Twenty of the cultivars were included as internal, noninoculated controls. The number of plants exhibiting early shoot symptoms (leaf flagging and wilting) in each treatment was recorded weekly for the duration of the experiment. Three months following inoculation, roots of surviving plants were washed, examined, and rated 1 to 5 on a disease scale based on symptoms (Table 1 ). The disease ratings data were analyzed using SigmaStat (SPSS Science, Chicago) statistical software. After analysis of variance (ANOVA) revealed significant differences among cultivars and between levels of inoculum (block effects were nonsignificant), mean separations were performed using least significant differences (LSD) or $t$ tests.

\section{Results and Discussion}

Leaf flagging and wilting were observed on some cultivars within 2 weeks of inoculation. Highly susceptible genotypes such as 'Blutopia', 'Roseum Elegans', and 'Edith Bosely' (Table 1) were killed 3 to 4 weeks postinoculation. All noninoculated controls had healthy shoots and roots by at the end of the 3-month experiment. Confirmation of predicted cultivar root rot ratings was observed in seven cultivars from a previous report (Hoitink and Schmitthenner, 1974) that were included 
Table 1. Mean root rot ratings of 57 rhododendron cultivars treated with one or more inoculum levels of $P$. cinnamomi.

\begin{tabular}{|c|c|c|c|}
\hline Cultivar $^{2}$ & $10 \mathrm{CFU}^{\mathrm{y}}$ & $30 \mathrm{CFU}^{\mathrm{y}}$ & Rating $^{\mathrm{x}}$ \\
\hline PJM Elite & 5.0 & --- & Susceptible \\
\hline Blutopia & 5.0 & 5.0 & \\
\hline Edith Bosely & 5.0 & 5.0 & \\
\hline Goldbukett & 5.0 & 5.0 & \\
\hline Lavendula & 5.0 & 5.0 & \\
\hline Mikkeli & 5.0 & 5.0 & \\
\hline Northern Starburst & 5.0 & 5.0 & \\
\hline Roseum Elegans ${ }^{\mathrm{w}}$ & 5.0 & 5.0 & \\
\hline White Peter & 5.0 & 5.0 & \\
\hline Haaga & 5.0 & 4.8 & \\
\hline Rangoon & 5.0 & 4.0 & \\
\hline Hachmann's Charmant & 5.0 & 3.5 & \\
\hline Firestorm & 4.5 & 5.0 & \\
\hline Nicoletta & 4.5 & 5.0 & \\
\hline Percy Wiseman & 4.5 & 5.0 & \\
\hline Chionoides $^{\mathrm{w}}$ & 4.5 & 4.0 & \\
\hline Hudson Bay & 4.3 & --- & \\
\hline Party Pink & 4.3 & 5.0 & \\
\hline Azurro & 4.3 & 4.3 & \\
\hline Fantastica & 4.3 & 4.0 & \\
\hline Besse Howells & 4.0 & 5.0 & \\
\hline Kalinka & 4.0 & 5.0 & \\
\hline Manitou & 4.0 & 5.0 & \\
\hline PJM Compact form & 4.0 & 5.0 & \\
\hline Wojnar's Purple & 4.0 & 5.0 & \\
\hline Arctic Pearl & 3.8 & 4.5 & \\
\hline Elviira & 3.8 & 4.5 & \\
\hline Bikini Island & 3.5 & 5.0 & \\
\hline Capistrano & 3.3 & 5.0 & \\
\hline Rio & 3.3 & 4.0 & \\
\hline Scarlet Romance & 3.0 & 5.0 & \\
\hline Sumatra & 3.0 & 5.0 & \\
\hline Tennessee & 3.0 & 5.0 & \\
\hline Trinidad & 3.0 & 5.0 & \\
\hline Oudijk's Sensationw & 3.0 & 4.3 & \\
\hline Summer Glow & 3.0 & 4.0 & \\
\hline Janet Blairw & 3.0 & 3.5 & \\
\hline Weston's Pink Diamond & 3.0 & 3.0 & \\
\hline Lavender Princess & 3.0 & 2.8 & \\
\hline Nova Zemblaw $^{\mathrm{w}}$ & 2.8 & 4.3 & \\
\hline Queen Alice & 2.8 & 3.5 & \\
\hline Hachmann's Polaris & 2.5 & 4.0 & \\
\hline Lee's Dark Purplew (rooted) & 2.0 & 5.0 & \\
\hline Golden Gala & 2.0 & 5.0 & \\
\hline Group mean & 3.9 & 4.6 & \\
\hline Samoa & 2.8 & 2.0 & Moderately resistant \\
\hline Anna H Hall & 2.5 & 2.8 & \\
\hline Hawaii & 2.5 & 2.3 & \\
\hline Peter Tigerstedt & 2.5 & 2.3 & \\
\hline Crete & 2.3 & 3.0 & \\
\hline Bali & 2.0 & 3.0 & \\
\hline Group mean & 2.4 & 2.6 & \\
\hline Caroline $^{\mathrm{w}}$ (rooted) & 2.0 & 1.5 & Highly resistant \\
\hline Brittany & 1.8 & 2.5 & \\
\hline Vernus & 1.8 & 2.5 & \\
\hline Rocket $^{\mathrm{w}}$ & 1.8 & 1.8 & \\
\hline Ginny Gee & 1.8 & 1.5 & \\
\hline Normandy & 1.5 & 2.3 & \\
\hline Ingrid Mehlquist & 1.3 & 2.5 & \\
\hline Group mean & 1.7 & 2.1 & \\
\hline $\mathrm{LSD}^{\mathrm{v}}$ & 2.1 & 1.5 & \\
\hline Root score grand mean & 3.4 & 4.0 & \\
\hline
\end{tabular}

"Except where indicated "rooted (cutting)," all comparisons were based on micropropagated plants.

${ }^{y}$ Mean root rot ratings after inoculation with 10 or $30 \mathrm{CFU}$ of $P$. cinnamomi. Scores are: 1 = healthy root; $2=$ necrosis of young, fine roots; 3 = necrosis of older, coarse roots; 4 = crown rot; and 5 = dead plant.

'Disease rating based on the average of a cultivar's root rot rating at both levels of inoculum. The ratings are "highly resistant" (average rating <2.3), "moderately resistant" (root rot ratings ranging from 2.3-2.7), and "susceptible" (ratings $>2.8$ ).

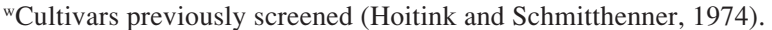

'Fisher's protected LSD, $P \leq 0.05$, across all cultivars at each inoculum level. in this study as susceptible and resistant controls (Table 1).

The distribution of root rot scores varied continuously from 1.3 (some necrosis on young roots) to 5.0 (severe root necrosis resulting in plant death; Table 1). No cultivar exhibited immunity to the disease. This continuum of response to infection is characteristic of host defense systems that are polygenically controlled. Rhododendrons may be similar in this respect to other taxa in which multiple genes are thought to control partial resistance to $P$. cinnamomi (Clark et al., 1986; Stukely and Crane, 1994).

As expected, an increase in the amount of inoculum resulted in a higher severity of disease. Overall root scores at the $30 \mathrm{CFU}$ level averaged 4.0 (Table 1) vs. an average root score of 3.4 at the $10 \mathrm{CFU}$ level, a difference that was significant ( $t$ test, $P \leq 0.01$ ). Experimental error was lower at the higher inoculation rate, resulting in a smaller least significant difference (LSD) value (Table 1) and a greater ability to separate mean differences in root scores. Among the 55 cultivars screened with both levels of inoculum, root rot scores were highly correlated ( $r=0.68, P \leq 0.01)$, suggesting that either level could be used to assess disease resistance with reasonable accuracy. In this study, the average of the two scores was used to classify cultivars as "susceptible," or as "moderately" to "highly" resistant (Table 1).

The inclusion of two inoculum levels was useful in rating the performance of cultivars and determining the degree of disease resistance. Cultivars with resistance at $10 \mathrm{CFU}$ inoculum and no resistance at 30 CFU (e.g., 'Golden Gala', 'Lee's Dark Purple', and 'Hachmann's Polaris'; Table 1) could be viewed as examples of low level, partial resistance to the pathogen. In contrast, resistant genotypes performed well at either level of inoculum. Mean root rot ratings for the six cultivars with moderate disease resistance were 2.4 at $10 \mathrm{CFU}$ and 2.6 at $30 \mathrm{CFU}$, while among the seven cultivars with high levels of resistance the corresponding root rot ratings were 1.7 and 2.1 (Table 1). Mean differences between the two inoculum levels within each resistance group were nonsignificant ( $t$ test).

This report confirms earlier observations that rhododendrons as a group are very susceptible to Phythophthora root rot, and demonstrates the need for development of additional resistant cultivars in the nursery industry. Of the cultivars in our sample, $77 \%$ had little or no resistance to the disease, compared with 94\% susceptibility in the earlier survey (Hoitink and Scmitthenner, 1974). Among azaleas, however, only $38 \%$ of the hybrids screened with $P$. cinnamomi showed severe root rot (Benson, 1980). These data indicate that genetic variation in root rot resistance occurs both within and between taxonomic groups of genus Rhododendron.

Rhododendron cultivars are usually derived from interspecific hybridizations, and their genetic backgrounds can be quite diverse, often containing many species in one hybrid. Collectively, the 13 resistant cultivars 
identified in this study include at least 14 different species from North America and Asia in their pedigrees (Salley and Greer, 1992). Most of these species also appear among the lineages of the susceptible cultivars, and so there is no obvious taxonomic relationship to root rot resistance. An exception may be $R$. keiskei, which shows little root damage in other screens we have performed (data not shown), and which makes up half the genetic contribution to the resistant cultivars 'Ginny Gee' and 'Brittany' (Table 1). The other species contributing to these two hybrids are considered to be uniformly susceptible ( $R$. minus in the case of 'Brittany') or quite variable in resistance ( $R$. racemosum in the pedigree of 'Ginny Gee') (Hoitink and Schmitthenner, 1974). Resistance to $P$. cinnamomi at the species level appears to be fairly uncommon

Table 2. Mean root rot ratings of conventionally propagated (Rooted) and micropropagated (TC) cultivars inoculated with P. cinnamomi. ${ }^{\mathrm{z}}$

\begin{tabular}{lccc}
\hline Cultivar & Rooted $^{\mathrm{y}}$ & $\mathrm{TC}^{\mathrm{y}}$ & $\Delta^{\mathrm{x}}$ \\
\hline Rangoon & 4.0 & 5.0 & $-1.0^{\mathrm{Ns}}$ \\
Janet Blair & 1.0 & 3.0 & $-2.0^{*}$ \\
Nova Zembla & 3.0 & 2.8 & $0.2^{\mathrm{Ns}}$ \\
Anna H Hall & 1.8 & 2.5 & $-0.7^{\mathrm{Ns}}$ \\
Crete & 2.5 & 2.3 & $0.2^{\mathrm{Ns}}$ \\
Brittany & 2.0 & 1.8 & $0.2^{\mathrm{Ns}}$ \\
Rocket & 2.5 & 1.8 & $0.7^{\mathrm{Ns}}$ \\
Rocket (30 CFU) & 1.5 & 1.8 & $-0.3^{\mathrm{Ns}}$ \\
Vernus & 2.5 & 1.8 & $0.7^{\mathrm{Ns}}$
\end{tabular}

${ }^{2}$ Except where indicated, inoculum level was 10 CFU per pot.

ySee Table 1 for explanation of root rot values.

${ }^{\mathrm{x}} \Delta=$ disease rating for rooted cultivar minus the rating for the same cultivar obtained from micropropagation.

Ns, ${ }^{*}$ Nonsignificant or significant at $P \leq 0.05$ ( $t$ test).
(Hoitink and Scmitthenner, 1974), making the few identified sources particularly valuable for breeding programs.

Comparisons of eight cultivars propagated from both tissue culture and rooted cuttings revealed that, in all but one case, the method of propagation did not significantly affect root rot ratings (Table 2). This result is encouraging because micropropagation is essential for the rapid introduction of new woody plant materials to the nursery industry. The exception was 'Janet Blair', where root rot ratings were significantly higher in micropropagated plants (root score $=3.0$ ) than in rooted cuttings (root score $=1.0$ ) at the same inoculum level. However, the performance of conventionally propagated 'Janet Blair' in this study is inconsistent with an earlier report that rated rooted cuttings of this cultivar as susceptible (Hoitink and Schmitthenner, 1974).

The disease-resistant rhododendrons identified in this report represent a useful germplasm pool for breeding for resistance to $P$. cinnamomi. The group of 13 cultivars is genetically diverse, and includes white, pink, and red flower colors (no yellow-flowered rhododendrons with root rot resistance have been found to date). They are all cold hardy to USDA zones 5 or 6 , and because they are mostly contemporary hybrids, they embody current tastes and trends in ornamental value.

While the genetic basis for resistance to root rot in rhododendrons has not been studied, research on other taxa indicates that the heritability of resistance to $P$. cinnamomi is high (Butcher et al., 1984; Clark et al., 1986; Stuckely and Crane, 1994). Gains in root rot resistance from a conventional breeding program involving crosses, screening, and selection could therefore be substantial. In addition, the diverse genetic backgrounds of the resis- tant rhododendrons raise the possibility that different resistance genes are present, and that these genes might be combined by hybridization to further enhance host defenses against this important pathogen.

\section{Literature Cited}

Benson, D.M. 1980. Resistance of evergreen hybrid azaleas to root rot caused by Phytophthora cinnamomi. Plant Dis. 64:214-215.

Benson, D.M. 1984. Influence of pine bark, matric potential, and $\mathrm{pH}$ on sporangium production by Phytophthora cinnamomi. Phytopathology 74:1359-1363.

Benson, D.M. 1987. Occurrence of Phytophthora cinnamomi on roots of azaleas treated with preinoculation and postinoculation applications of metalaxyl. Plant Dis. 87:818-820.

Butcher, T.B., M.J.C. Stukely, and G.W. Chester. 1984. Genetic variation in resistance of Pinus radiatus to Phytophthora cinnamomi. For. Ecol. Mgt. 8:197-220.

Clark, J.R., J.N. Moore, and A.D. Draper. 1986. Inheritance of resistance to Phytophthora root rot in highbush blueberry. J. Amer. Soc. Hort. Sci. 111:106-109.

Hoitink, H.A.J. and A.F. Schmitthenner. 1974. Resistance of Rhododendron species and hybrids to Phytophthora root rot. Plant Dis. Rpt. 58:650 653.

Hoitink, H.A.J., D.M. Vandoren, and A.F. Schmitthenner. 1977. Suppression of Phytophthora cinnamomi in a composted hardwood bark potting medium. Phytopathology 67:561-565.

Salley, H.E. and H.E. Greer. 1992. Rhododendron hybrids. Timber Press, Portland, Ore.

Schmitthenner, A.F. and R.G. Bhat. 1994. Useful methods for studying Phytophthora in the laboratory. Ohio Agr. Res. Dev. Ctr. Spec. Circ. 143 , Ohio State Univ.

Stukely, M.J.C. and C.E. Crane. 1994. Genetically based resistance of Eucalyptus marginata to Phytophthora cinnamomi. Phytopathology 84:650-656. 